\title{
The Effect of Using Wastewater from Stone Industry in Replacement of Fresh Water on the Properties of Concrete
}

\author{
Nabil Joulani ${ }^{1}$, Riyad Abdel-Karim Awad ${ }^{2}$ \\ ${ }^{1}$ Palestine Polytechnic University, Hebron, Palestine \\ ${ }^{2}$ An-Najah National University, Nablus, Palestine \\ Email: njoulani@ppu.edu
}

How to cite this paper: Joulani, N. and Awad, R.A.-K. (2019) The Effect of Using Wastewater from Stone Industry in Replacement of Fresh Water on the Properties of Concrete. Journal of Environmental Protection, 10, 276-288.

https://doi.org/10.4236/jep.2019.102016

Received: January 7, 2019

Accepted: February 16, 2019

Published: February 19, 2019

Copyright $\odot 2019$ by author(s) and Scientific Research Publishing Inc. This work is licensed under the Creative Commons Attribution International License (CC BY 4.0).

http://creativecommons.org/licenses/by/4.0/

\begin{abstract}
This research presents an attempt of using wastewater from stone slurry waste in production of concrete. Several concrete mixtures were prepared by using tap water and stone slurry wastewater at different $\mathrm{w} / \mathrm{c}$ ratios and replacement ratios of wastewater in substitute of tap water. Testing of concrete samples included slump, compressive strength, flexural strength and absorption. Test results showed reduction of workability (slump) at all w/c ratios and replacement ratios. The maximum compressive strength didn't change significantly at $\mathrm{w} / \mathrm{c}=0.7$ and 28 days of curing compared with compressive strength at $\mathrm{w} / \mathrm{c}=0.5$ and 0.6 . From linear regression of the experimental results, the results showed that at $20 \%$ replacement ratio of tap water with wastewater, the reduction in compressive strength was insignificant (not greater than $10 \%$ to $15 \%)$. Test results showed varying reduction of absorption at different $\mathrm{w} / \mathrm{c}$ and replacement ratios, up to $62 \%$ at $\mathrm{w} / \mathrm{c}=0.5$.
\end{abstract}

\section{Keywords}

Reuse, Stone Slurry Wastewater, Concrete, Cast Stones

\section{Introduction}

The production of building stone is one of the important professions in Palestine. The source of stone is from about 400 stone quarries situated across the West Bank. There are approximately 1000 stone cutting facilities in the West Bank and Gaza. The stone and marble sector is having the largest percentage of employment of Palestinian labor force with more than 13500 workers. The annual Palestinian production of finished stone and marble is 16 million square 
meters, equaling to 1.6 million. The stone and marble sector contributes approximately $25 \%$ of Palestine's overall industrial revenue and $4.5 \%$ of the total Palestinian GNP. The annual revenue of this industry is estimated at $\$ 450$ million [1].

Clearly, the potential of the stone industry is very large. However, many problems and challenges on the national and industry level remain to be addressed in order to realize these potential gains.

In all stone cutting facilities the rocks are cut and shaped. Water is primarily used as a cooling, lubricating and cleaning agent for preventing dust generation during the sawing and polishing processes. Therefore, the stone cutting industry is considered to be the largest consumer of fresh water and producer of wastewater and solid waste in the West Bank, and of air-born pollutants. The stone slurry waste is a viscous material resulted from sawing, shaping and polishing process. It contains approximately $65 \%$ of water. The stone slurry is usually disposed in open areas causing many health problems, land contamination and sewerage network blockage. In 2012 the Israeli authority threatened to closer the whole industrial zone in Hebron as consequences of random dumping of the stone slurry waste. Therefore, the US agency for international development (USAID) sponsored an emergency project for management of the stone slurry waste in Hebron. The project was implemented by Black and Veach Company [2]. Black and Veach Company transported about 196,674 cubic meters of stone slurry waste to sediment pools in one year. Many attempts have been made locally and worldwide to solve the stone slurry waste problem by using it in its viscous state or after drying. The main potential application of the stone slurry waste is in production of construction materials.

This research is an attempt to partially solve the problem of stone slurry waste by using the wastewater as partial replacement of fresh water in production of ready mix concrete. The compressive strength and absorption of hardened concrete were tested along with slump of fresh concrete. Using amounts of the stone slurry wastewater in concrete production may save large amounts of fresh water annually, for domestic use in Palestine. Figure 1 shows some photos for discharge of stone slurry waste in open areas and in agricultural lands.

\section{Literature Review}

In an age of increasing human population and scarce water recourses, coupled with environmental impact of wastewater resulting from different industrial activities, many researchers all over the world started to think of partial replacement of tap water by treated wastewater for production of ready mix concrete production.

Kadir et al. [3] studied the effect of slurry water as a fresh water replacement in concrete properties. They concluded that the concrete with $20 \%$ replacement of slurry water achieved the higher compressive strength compared to other percentages. 


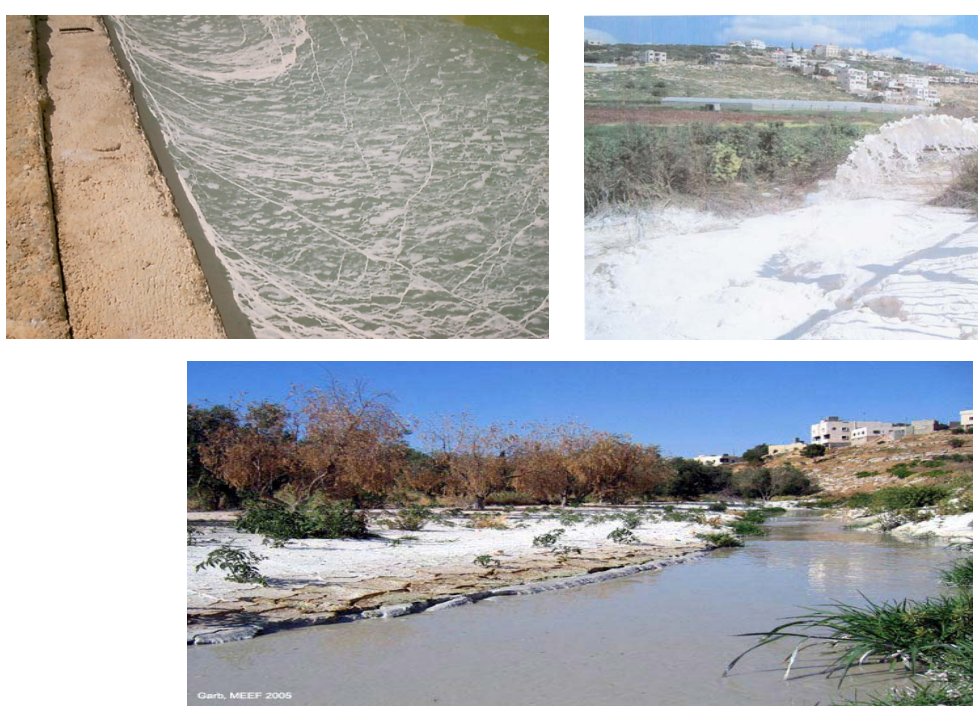

Figure 1. Stone slurry wastewater generation and discharge out in open areas.

Alzboon and Mahasneh [4] reported that $96 \%$ of the stone slurry sludge volume is water, and should be considered as an important source of water. $\mathrm{He}$ used the stone slurry sludge in concrete production. The results showed insignificant effect on compressive strength but sharp reduction in slump values. The results showed that using stone slurry sludge with $25 \%$ of the total water content obtained successful concrete samples regarding slump and compressive strength.

Al-Ghusain and Terro [5] concluded that tertiary treated wastewater of the type produced from the wastewater treatment plants in Kuwait was found to be suitable for mixing concrete without adverse effects.

Mahasneh [6], from Jordan, carried out an experimental work to evaluate the effect of using treated wastewater on the properties of concrete in comparison to the same properties using fresh water. He concluded that that there was an average reduction of $7.3 \%$ in the compressive strength of concrete cube samples prepared using treated wastewater, however this complies with British Standards and AASHTO standards which require that compressive strength of cubes made of waste water not be less than $90 \%$ of the compressive strength of cubes made of tap water.

Kucche et al. [7] reviewed the literature related to the quality of water for making concrete. The allowable limits of physical and chemical impurities and the test methods of their evolution are compiled from different standards. The main finding was the reaction between water and cement affect the setting time, compressive strength and lead to softening of concrete. All the impurities may not have adverse effect on the properties of concrete.

More and Dubey [8] investigated the effect of different types of water on the compressive strength of concrete. The results showed that while the compressive strength of the concrete cubes increased by time not much variation in strength was noticed by using the different types of used water: mineral water, tap water, well water and wastewater. 
Al-Jabri et al. [9] investigated the effect of using wastewater on the properties of high strength concrete. Chemical analysis results showed that although the chemical composition of the wastewater were much higher than the tap water parameters, the water composition was within the ASTM standard limits for all substances indicating that the produced wastewater can be used satisfactorily in concrete mixes. The percentage of wastewater replaced changed between $25 \%$ $100 \%$ of tap water used in concrete. Results indicated that the strength of concrete of the mixtures prepared using wastewater was comparable to the strength of control mix.

Olugbenga [10] from Nigeria studied the effects of different sources of water on concrete strength due to scarcity of water in this African country. He investigated the effect of different types of water on the compressive strength of concrete. The effect of the presence of some impurities like silt and suspended particles on the strength of concrete was also investigated. He concluded that the sources of water have a significant impact on the properties of concrete.

\section{Objectives}

This study focuses on the utilization of wastewater from the stone slurry waste in production of ready mix concrete, the main objectives of this study are:

- To provide opportunity for beneficial reuse of industrial liquid waste in construction materials.

- To provide opportunity for water reclamation from stone cutting industry.

- And overall to paramount health, safety, and welfare of the public.

Adoption and implementation of the research results will contribute to saving of at least 0.5 million $\mathrm{m}^{3}$ of fresh water annually, protecting the environment from the industrial pollution, enhancement of public health and welfare and providing economic befits due to reduction in water consumption.

\section{Methodology}

In this study a battery of data collection tools were adopted to ensure that all types of data required are collected.

1) The most prominent tool was the questionnaire that was specially designed to benefit in gathering the required data. In building the questionnaire, the project team benefited from the previous studies, publications on recycling of building materials, and the experts points of views. It was distributed to selected key persons working in the field of stone cutting in the Governorate of Hebron.

2) Interviews were also conducted with selected key persons in some of the companies and local government personnel (engineers, mayors, etc), those helped in crystallizing the questionnaire and enhancing the perception of recycling of stone cutting plants in the Palestinian context. The interviews questions are related the questionnaire, and focus on the opinion of interviewed persons about the issue of using wastewater from stone slurry in the production of concrete. 
3) Documentary analysis was another tool for data collection in different data bases at the union of stone and marble, the Palestinian environmental authority and the literature. The targeted documents were: recycling related reports, regulations and bylaws... etc., and this tool provided the study with facts related to current practice in dealing with recycling of stone slurry waste in building materials in Palestine.

4) Site visits were conducted for different stone cutting plants in Al Fahs area, the Governorate of Hebron.

5) Samples of concrete were produced by different w/c and replacement ratios of wastewater in substitute of fresh mixing water. The samples were cured and tested in the Palestine Polytechnic University (PPU) labs, during 2018.

The results presented in this research are for the questionnaire and the experimental work results.

The questionnaire covered about 28 stone cutting plant in the study area - in Hebron City in the West Bank. The total monthly quantity of water consumed by the 28 stone cutting plants is about 6840 cubic meters and the average quantity for each plant is about 244 cubic meters per month.

The 28 stone cutting plants produce about 4950 cubic meter of slurry which contains about $65 \%-70 \%$ of water. The average for each plant is more than 177 cubic meter of slurry per month which contains about $0.7 \times 177=124$ cubic meters of water.

From the questionnaire also, it was found that large quantities of fresh water consumed by the ready mix concrete plants. About 26,000 cubic meter of fresh water is consumed every month in 10 ready mixed concrete plants (about 2600 cubic meter for each plant) of water monthly.

\section{Experimental Program}

The experimental work was based on preparing different concrete mixes at the stone and marble center at Palestine Polytechnic University (PPU). The mixes were changed by using three different $\mathrm{W} / \mathrm{C}$ ratios $(0.5,0.6$, and 0.7$)$. The reference mix was made by using fresh water (tap water). Many other concrete mixes with the same W/C ratio, were made using stone slurry wastewater in replacement of fresh water at different percentages. A total of 24 concrete mixes were explored at different replacement ratios of wastewater (SW). The constituent's ratios of the different concrete mixes are shown in Table 1.

\subsection{Mixing Water}

The appropriate water for mixing is potable water, and the specifications (ASTM C94) [11], usually stipulate that the water must be free of chloride, sulfate and salts and is also free from harmful substances such as oils, grease, acids, alkalis, organic matters, cork and other substances that have a reverse effect on concrete in terms of resistance to fracture and durability.

The stone slurry wastewater has TSS of around 12,000 mg/l, leading to high maintenance cost of sewage network, and its low $\mathrm{PH}$ lead to harmful of agricultural 
Table 1. Concrete mixtures constituents.

\begin{tabular}{cccccc}
\hline $\begin{array}{c}\text { Water Type, } \\
\text { Replacement \%, } \\
\text { (w/c Ratio) }\end{array}$ & $\begin{array}{c}\text { Portland } \\
\text { Cement Type 1 } \\
\left(\mathrm{kg} / \mathrm{m}^{3}\right)\end{array}$ & $\begin{array}{c}\text { Water } \\
\left(\mathrm{kg} / \mathrm{m}^{3}\right)\end{array}$ & $\begin{array}{c}\text { Sludge } \\
\text { Water } \\
\left(\mathrm{kg} / \mathrm{m}^{3)}\right.\end{array}$ & $\begin{array}{c}\text { Fine } \\
\text { Aggregate } \\
(\text { Sand }) \\
\left(\mathrm{kg} / \mathrm{m}^{3)}\right.\end{array}$ & $\begin{array}{c}\text { Coarse Aggregate } \\
(\text { Crushed Limestone }) \\
\left(\mathrm{kg} / \mathrm{m}^{3}\right)\end{array}$ \\
\hline Tap W (0.5) & 347 & 174 & 0 & 896 & 956 \\
Tap W (0.6) & 309 & 185 & 0 & 896 & 956 \\
Tap W (0.7) & 279 & 195 & 0 & 896 & 956 \\
SW30 (0.5) & 347 & 121 & 52 & 896 & 956 \\
SW30 (0.6) & 309 & 130 & 55 & 896 & 956 \\
SW30 (0.7) & 279 & 137 & 58 & 896 & 956 \\
SW100 (0.5) & 347 & 0 & 173 & 910 & 966 \\
SW100 (0.6) & 309 & 0 & 185 & 910 & 966 \\
SW100 (0.7) & 279 & 0 & 195 & 910 & 966 \\
\hline
\end{tabular}

SW: Stone slurry wastewater.

land, furthermore, the discharge areas of slurry stone wastewater in Palestine are located in the recharge areas of principle aquifers used for drinking water supply, the eastern and western aquifers. The stone slurry wastewater is treated in the stone cutting plants by using coagulant agent to accelerate sedimentation of the fine suspended particles. Three samples of stone slurry wastewater treated by sedimentation were tested.

The water samples have a $\mathrm{pH}$ of 7.98 (between 6 and 8) which complies with the findings of Neville [12], who concluded that water having a $\mathrm{pH}$ in this range have no significant effect on compressive strength of concrete. According to BS 3148 , the permissible limit of total dissolved solids (TDS) is $2000 \mathrm{ppm}$. All water samples tested have their TDS within the acceptable limits. Table 2 shows the chemical properties of the stone slurry wastewater used in the research:

\subsection{Properties of Fresh and Hardened Concrete}

Slump test was conducted for each concrete mixture made with tap water and stone slurry wastewater at $\mathrm{w} / \mathrm{c}$ ratios and different percentages of wastewater replacement of fresh water. The hardened samples were tested for compressive strength after 7, 14, and 28 days, flexural strength and absorption after 28 days. Figure 2 shows the slump test of fresh concrete mixture, curing and testing of hardened concrete samples.

\section{Results and Discussion}

\subsection{Concrete with Tap Water}

Figures 3-5 present the stress-strain relationship of concrete samples made with tap water and used as reference for further comparison of concrete made with stone slurry wastewater. Figure 6 shows the variation of max compressive stress with $\mathrm{w} / \mathrm{c}$ ratio and curing time. 
Table 2. Properties of stone slurry wastewater used.

\begin{tabular}{|c|c|c|c|}
\hline Test & Units & Results & Ref \\
\hline $\mathrm{pH}$ & -- & 7.98 & SMWW \\
\hline Turbidity & NTU & 9.3 & SMWW \\
\hline $\mathrm{NO}_{3}$ & $\mathrm{Mg} / \mathrm{L}$ & 50.92 & SMWW \\
\hline $\mathrm{SO} 4$ & $\mathrm{Mg} / \mathrm{L}$ & 20.27 & SMWW \\
\hline Total Hardness as $\left(\mathrm{CaCo}_{3}\right)$ & $\mathrm{Mg} / \mathrm{L}$ & 280 & SMWW \\
\hline Total Alkalinity as $\left(\mathrm{CaCo}_{3}\right)$ & $\mathrm{Mg} / \mathrm{L}$ & 210 & SMWW \\
\hline TDS & $\mathrm{Mg} / \mathrm{L}$ & 433.5 & SMWW \\
\hline TSS & $\mathrm{Mg} / \mathrm{L}$ & 38 & SMWW \\
\hline $\mathrm{Ca}$ & $\mathrm{Mg} / \mathrm{L}$ & 48 & SMWW \\
\hline $\mathrm{Mg}$ & $\mathrm{Mg} / \mathrm{L}$ & 39 & SMWW \\
\hline $\mathrm{Na}$ & $\mathrm{Mg} / \mathrm{L}$ & 60.1 & SMWW \\
\hline $\mathrm{K}$ & $\mathrm{Mg} / \mathrm{L}$ & 8.3 & SMWW \\
\hline $\mathrm{Al}_{2} \mathrm{O}_{3}$ & $\%$ & $<0.001$ & SMWW \\
\hline $\mathrm{Fe}_{2} \mathrm{O}_{3}$ & $\%$ & 0.003 & SMWW \\
\hline $\mathrm{CaO}$ & $\%$ & 2.88 & SMWW \\
\hline $\mathrm{MgO}$ & $\%$ & 0.106 & SMWW \\
\hline $\mathrm{SO}_{3}$ & $\%$ & 0.003 & SMWW \\
\hline $\mathrm{Cl}^{-}$ & $\%$ & 0.011 & SMWW \\
\hline LOI & $\%$ & 97.6 & SMWW \\
\hline
\end{tabular}

SMWW: Standard methods of water and wastwater (An-Najah Univ. labs.).
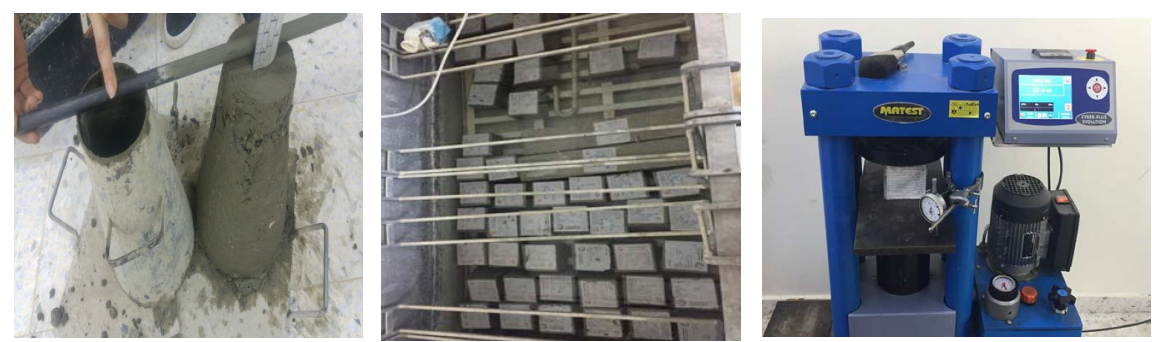

Figure 2. Slump test, curing and compressive stress tests of concrete.

\subsection{Concrete with Stone Slurry Wastewater}

\subsubsection{Slump Test Results}

Table 3 shows the variation of slump test results with different $w / c$ ratios and replacement ratio. The workability decreased tremendously at replacement ratio of $30 \%$ and $100 \%$, compared with workability of concrete with tap water.

It is noticed that replacement of mixing fresh water with $30 \%$ and $100 \%$ of stone slurry wastewater reduces the slump more than $85 \%$ at $w / c=0.7$. On the other hand, at $\mathrm{w} / \mathrm{c}=0.5$ and replacement ratio of $100 \%$ the slump reduced by $50 \%$, while at $30 \%$ replacement the slump did not affected significantly. From 


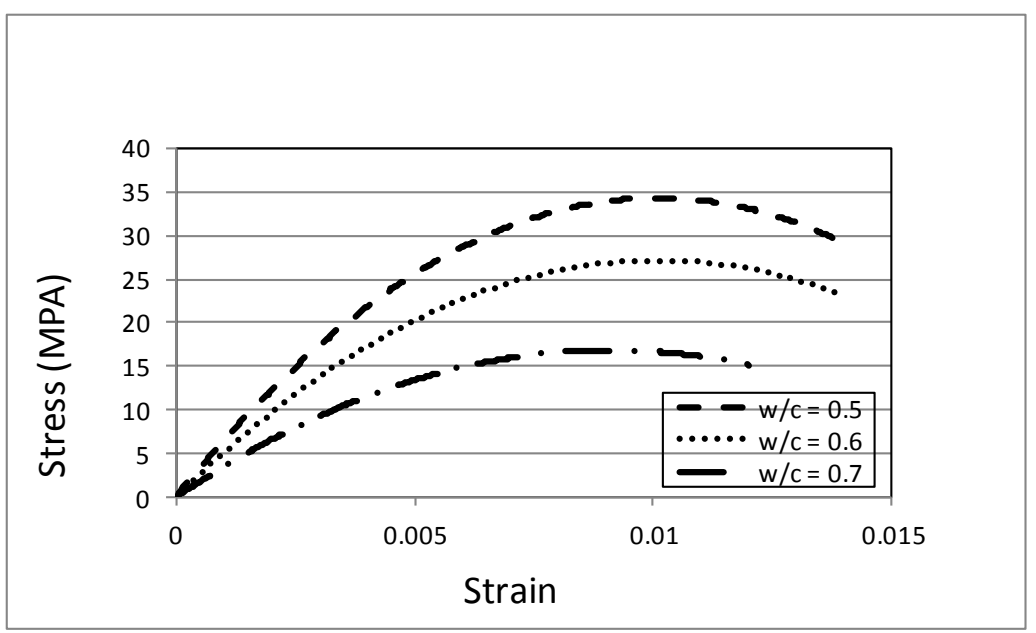

Figure 3. Compressive strength of concrete made with tap water at 7 days curing.

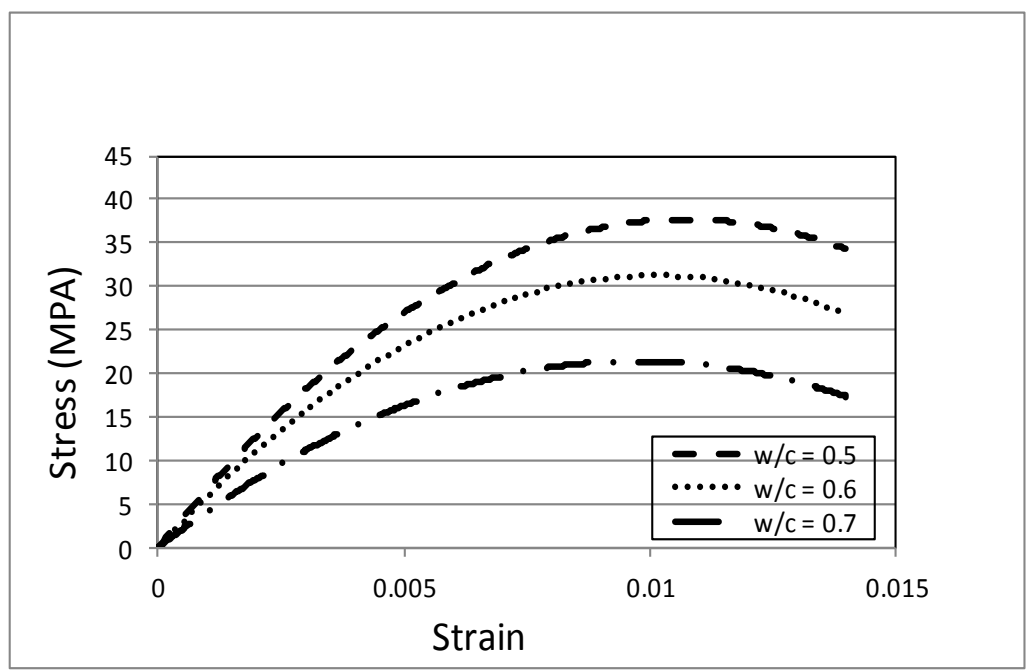

Figure 4. Compressive strength of concrete made with tap water at 14 days curing.

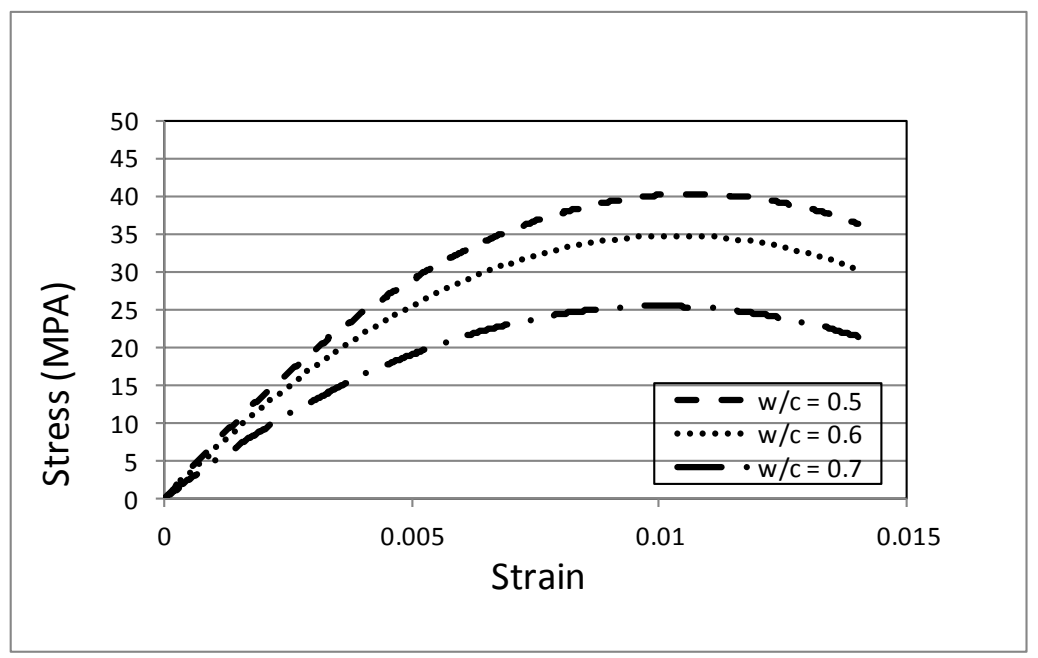

Figure 5. Compressive strength of concrete made with tap water at 28 days curing. 


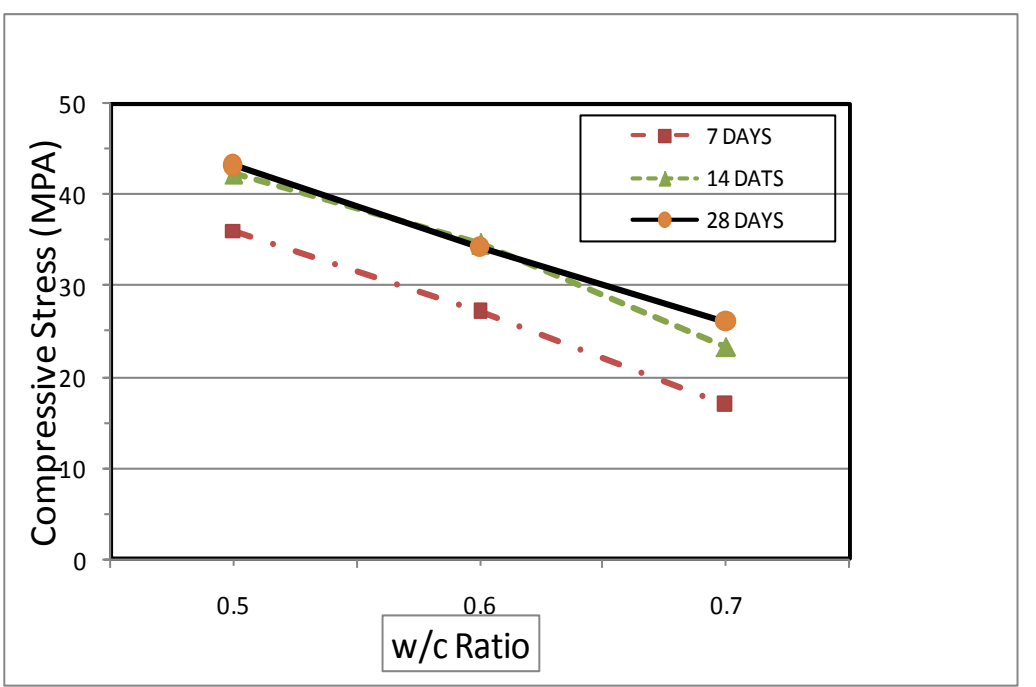

Figure 6. Variation of max compressive strength of concrete with w/c ratio and age.

Table 3. Comparison of slump test of fresh concrete.

\begin{tabular}{cccc}
\hline Type of Water & SW $\%$ & w/c & Slump (mm) \\
\hline Tap water & 0 & 0.5 & 20 \\
& 0 & 0.6 & 100 \\
& 0 & 0.7 & 220 \\
Stone wastewater with & $30 \%$ & 0.5 & 17 \\
flocculent & $30 \%$ & 0.6 & 25 \\
& $100 \%$ & 0.7 & 31 \\
& $100 \%$ & 0.5 & 10 \\
& $100 \%$ & 0.6 & 23 \\
\hline
\end{tabular}

these results we may conclude that using stone slurry wastewater in general will reduce workability tremendously and more superplasticizer agent should be used to increase workability.

\subsubsection{Compressive Stress Results}

Table 4 shows the variation of compressive stress of concrete at different replacement ratio of tap water with stone slurry wastewater and for different ages.

It is noticed that compressive stress increased at $\mathrm{w} / \mathrm{c}$ ratio $=0.6$ after 7 days at replacement ratio $(\mathrm{SW})=30 \%$, and at $\mathrm{w} / \mathrm{c}$ ratio $=0.7$ after 7 days with $\mathrm{SW}=$ $30 \%$ and $\mathrm{SW}=100 \%$.

Figures 7-9 show the linear regression trend of compressive stress with different replacement and $\mathrm{w} / \mathrm{c}$ ratios and curing time.

By taking maximum compressive stress at $20 \%$ replacement of fresh water with stone slurry wastewater, the reduction of compressive will be less about 
Table 4. Comparison of maximum compressive stress at different replacement ratios of wastewater, for different ages.

\begin{tabular}{|c|c|c|c|c|c|c|}
\hline \multirow{4}{*}{$w / c$} & \multirow{4}{*}{ Age (Days) } & \multicolumn{3}{|c|}{$\%$ Replacement of Wastewater } & \multicolumn{2}{|c|}{$\begin{array}{c}\text { \% Replacement of } \\
\text { Wastewater }\end{array}$} \\
\hline & & & & & $30 \%$ & $100 \%$ \\
\hline & & $0 \%$ & $30 \%$ & $100 \%$ & \multirow{2}{*}{\multicolumn{2}{|c|}{ \% Change in Max. Stress }} \\
\hline & & \multicolumn{3}{|c|}{ Maxim Stress (MPa) } & & \\
\hline \multirow{3}{*}{0.5} & 7 & 36.1 & 25.4 & 21.5 & $30 \%$ & $40 \%$ \\
\hline & 14 & 42.3 & 27.6 & 27.7 & $35 \%$ & $34 \%$ \\
\hline & 28 & 43.2 & 31.6 & 18.1 & $27 \%$ & $58 \%$ \\
\hline \multirow{3}{*}{0.6} & 7 & 27.27 & 28.3 & 25.9 & $+4 \%$ & $-5 \%$ \\
\hline & 14 & 34.6 & 31.5 & 12.6 & $-9 \%$ & $-63 \%$ \\
\hline & 28 & 34.3 & 38 & 18.3 & $-11 \%$ & $-47 \%$ \\
\hline \multirow{3}{*}{0.7} & 7 & 16.9 & 27.7 & 24.6 & $+64 \%$ & $+31 \%$ \\
\hline & 14 & 23 & 14.57 & 25.3 & $-37 \%$ & $+10 \%$ \\
\hline & 28 & 26.1 & 17.8 & 33.1 & $-32 \%$ & $+27 \%$ \\
\hline
\end{tabular}

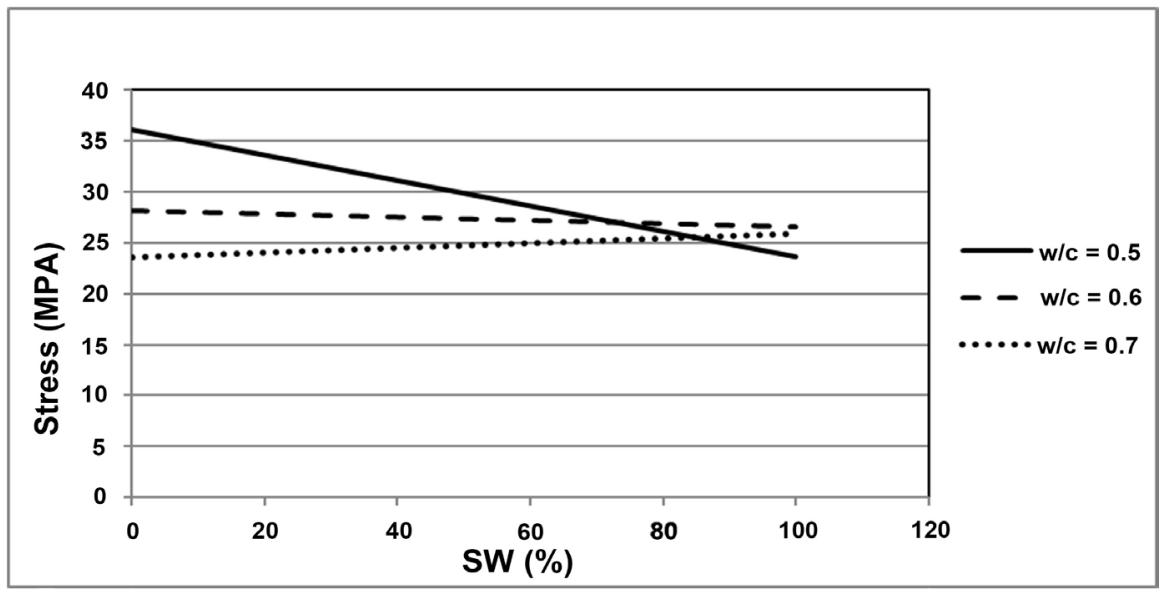

Figure 7. Variation of compressive strength with stone slurry wastewater percent at different $w / c$ ratios after 7 days curing.

$15 \%$. Therefore, we may suggest using wastewater from stone slurry as replacement of fresh water in production of low strength concrete or non-structural plane concrete.

\subsubsection{Absorption Test Results}

Table 5 shows the variation of natural absorption after 28 days curing of concrete samples made with the stone slurry wastewater compared with absorption of samples made with tap water at the same age. It is noticed that absorption reduced more than $50 \%$ upon replacement of fresh water with stone slurry wastewater by $30 \%$ and $100 \%$.

The reduction of max compressive strength, slump, water absorption, when using stone slurry wastewater in replacement of tap water in concrete production, 


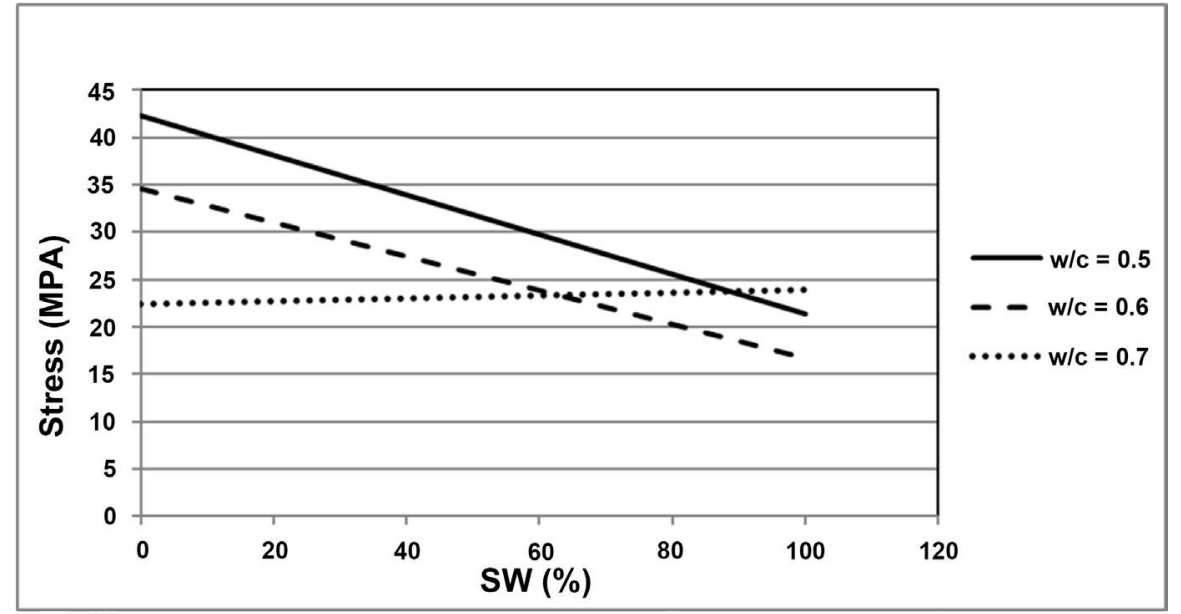

Figure 8. Variation of compressive strength with stone slurry wastewater percent at different $\mathrm{w} / \mathrm{c}$ ratios after 14 days curing.

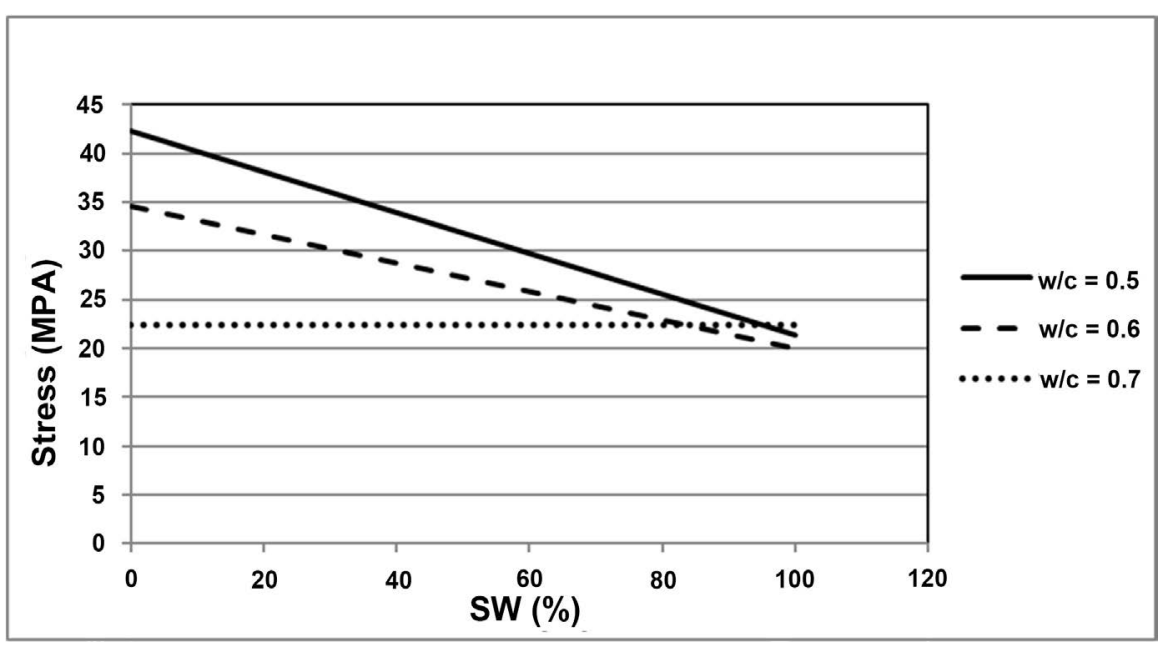

Figure 9. Variation of compressive strength with stone slurry wastewater percent at different $\mathrm{w} / \mathrm{c}$ ratios after 28 days curing.

Table 5. Comparison of absorption of different samples.

\begin{tabular}{ccc}
\hline Water Type/(SW \%) & w/c & Absorption after 28 Days (\%) \\
\hline Tap water (SW 0\%) & 0.5 & 5.84 \\
& 0.6 & 2.40 \\
Stone wastewater (SW 30\%) & 0.7 & 2.01 \\
& 0.5 & 2.21 \\
& 0.6 & 2.41 \\
Stone wastewater (SW 100\%) & 0.7 & 2.36 \\
& 0.5 & 2.88 \\
& 0.6 & 2.74 \\
\hline
\end{tabular}


may be attributed to the fine suspended particles and chemical solvent available in the slurry stone wastewater.

\section{Conclusions and Recommendations}

1) Results showed that using wastewater from stone slurry waste at $w / c=0.7$ in concrete mixtures did not affect maximum compressive stress after 28 days of curing.

2) At $w / c=0.5$ and 0.6 the results showed varying reduction in maximum compressive stress after 28 days of curing.

3) The replacement of tap water with stone slurry wastewater caused substantial slump reduction at $\mathrm{w} / \mathrm{c}=0.6$ and 0.7 , but minor effect on slump was noticed at $\mathrm{w} / \mathrm{c}=0.5$ and replacement ratio, $\mathrm{SW}=30 \%$.

4) The natural absorption of concrete increased at w/c $=0.6$ and 0.7 by $(8 \%$ $27 \%)$, but decreased at $\mathrm{w} / \mathrm{c}=0.5$ up to $59 \%$.

5) Linear regression of the experimental results suggests using stone slurry wastewater only at replacement ratio of SW $=20 \%$. This replacement ratio is in agreement with some results cited in the literature and will produce concrete with acceptable properties.

The stone slurry wastewater may be used in replacement of tap water in production of non-structural, low strength concrete or plain concrete, at $w / c=0.7$ and replacement ratio of SW $=100 \%$.

\section{Acknowledgements}

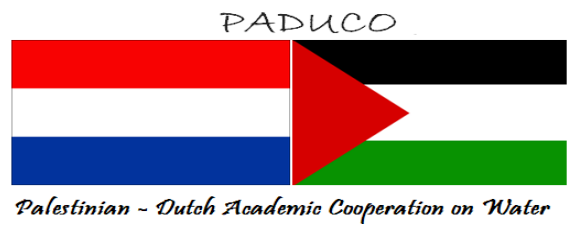

This paper is part of the Palestinian-Dutch Cooperation on Water (PADUCO-2) Project. The Sponsorship of Dutch Government is appreciated.

\section{Conflicts of Interest}

The authors declare no conflicts of interest regarding the publication of this paper.

\section{References}

[1] USM (2011) Stone and Marble in Palestine, Developing a Strategy for the Future.

[2] Black \& Veatch (2012) Emergency Disposal of Industrial Stone Cutting Waste, Hebron, Palestine. Black \& Veatch, Overland Park.

[3] Kadir, A.A., Shahidan, S., Yee, L.H., Hassan, M.I.H. and Al Bakri Abdullah, M.M. (2016) The Effect of Slurry Water as a Fresh Water Replacement in Concrete Properties. IOP Conference Series. Materials Science and Engineering, 133, Article ID: 012041. https://doi.org/10.1088/1757-899X/133/1/012041

[4] Alzboon, K. and Mahasneh, K. (2009) Effect of Using Stone Cutting Waste on the Compression Strength and Slump Characteristics of Concrete. International Journal 
of Environmental Science and Engineering, 4, 167-172.

[5] Al-Ghusain, I. and Terro, I. (2003) Use of Treated Wastewater for Concrete Mixing in Kuwait. Kuwait Journal of Science \& Engineering, 30.

[6] Mahasneh, B. (2014) Assessment of Replacing Wastewater and Treated Water with Tap Water in Making Concrete Mix. The Electronic Journal of Geotechnical Engineering, 19, 2379-2386.

[7] Kucche, M.K., Jamkar, S. and Sadgir, P. (2015) Quality of Water for Making Concrete: A Review of Literature.

[8] More, R.A. and Dubey, S.K. (2014) Effect of Different Types of Water on Compressive Stress of Concrete. International Journal of Emerging Technologies, 5, 40-50.

[9] Al-Jabri, K.S., et al. (2011) Effect of Using Wastewater on the Properties of High Stress Concrete. Elsevier Proceeding Engineering, 14, 370-376.

[10] Olugbenga, A.T.A. (2014) Effects of Different Sources of Water on Concrete Stress: A Case Study of Ile-Ife. Civil and Environmental Research, 6, 39-43.

[11] ASTM C-94 (1996) Standard Specification for Ready Mix Concrete. American Society of Testing and Materials, West Conshohocken.

[12] Neville, A.M. (2012) Properties of Concrete. Prentice Hall, Upper Saddle River. 